\title{
Viešųjų paslaugų tyrimų kryptys: kokybinio požiūrio plètros poreikio pagrindimas
}

\author{
Marius Urvikis \\ Mykolo Romerio universitetas \\ Valakupiu g. 5, LT-10101 Vilnius, Lietuva \\ doi:10.13165/VPA-14-13-2-08
}

\begin{abstract}
Anotacija. Šio straipsnio tikslas - išanalizuoti kokybinio požiūrio svarbą viešuju paslaugu tyrimuose, išryškinant squveikos tarp suinteresuotujų reguliavimo bei procesu valdymo reikšmę. Straipsnyje apžvelgiamos viešuju paslaugu tyrimu teorinès ir metodologinès prieigos. Atskleidžiant viešuju paslaugu teikimo organizavimo ir vertinimo problematika bei i procesus orientuotos veiklos logikos teorinius aspektus, pagrindžiamas kokybiniu tyrimu plètros poreikis. Straipsniu nesiekiama menkinti kiekybiniu tyrimu ịtaka ar neigti ju naudą organizuojant viešuju paslaugu teikima, tačiau daroma išvada, jog tikslinga derinti kiekybinès metodologijos ir kokybinio požiūrio elementus. Teigiama, kad kokybine analize leidžia visapusiškai suvokti viešuju paslaugu teikimo problemas, apie kurias kiekybiniais metodais surenkami duomenys signalizuoja sąlygojančiu procesu ir veiksniu priežastinius ryšius. Akcentuojamos kokybinio požiūrio galimybès priimant sprendimus, igalinančius teikiant paslaugas išnaudoti visuomenès ir verslo pajègumus bei leidžiančius pašalinti konstruktyvios suinteresuotuju viešuju paslaugu teikimu squveikos, kaip esminio viešojo sektoriaus konkurencinguma lemiančio veiksnio, trukdžius.
\end{abstract}

Raktažodžiai: viešosios paslaugos, visuomenès pasitikejjimas, kokybinis požiūris, i procesus orientuota veiklos logika. logic.

Keywords: public services, public trust, qualitative approach, service-dominant

\section{İvadas}

Šiuolaikiniame viešojo valdymo kontekste sprendimų prièmimas nebėra išimtinai politikų prerogatyva. Viešojo sektoriaus reformos yra nukreiptos ị piliečių 
pasitikèjimo valdžios institucijomis didinimą, kurị didele dalimi lemia gaunamų viešųjų paslaugų atitiktis jų vartotojų lūkesčiams. Naujajam viešajam valdymui artimy koncepciju turinys bei visuomenès institucionalizavimas reikalauja analitinio sprendimų pagrindimo ir kokybiškų, tyrimais pagrịstų bei tinkamai interpretuojamų duomenų kaip pagrindo viešojo sektoriaus veiklos tobulinimui.

Vykdant viešojo sektoriaus reformas naujoji viešoji vadyba palaipsniui buvo depolitizuota, o jos akcentuotos ekonominès vertybès ir gamybinio viešųjų paslaugų efektyvumo dimensijos tapo etalonu visoms viešojo sektoriaus institucijoms visose valstybinès veiklos srityse. Kartu išpopuliarejo ir ekonomikos mokslo metodologijai artimi kiekybiniai viešųjų paslaugų tyrimų metodai. Nors po naujosios viešosios vadybos sukurti modeliai ir koncepcijos akcentuoja, jog paslaugų teikimas viešajame sektoriuje apima kur kas daugiau negu vien tik paslaugos turini, o viešojo valdymo procesai ilgalaikejje perspektyvoje yra ne mažiau svarbūs negu finansiniais rodikliais išreiškiami rezultatai, tačiau istoriškai ịsišaknijusi kiekybine viešųjų paslaugų tyrimų metodologija vis dar yra mažai papildoma kokybinio požiūrio elementais bei atitinkamais tyrimų metodais.

Viešųjų paslaugų kokybės tyrimai skatina kontroversiškus debatus. Dažnai apsiribojama statistine pasitenkinimo viešosiomis paslaugomis analize, kuri nesiūlo problemų sprendimų, o tik iškelia prielaidas dèl paslaugos kaip produkcijos tobulinimo poreikio. Viešųjų paslaugų kokybès samprata integruoja daugybę skirtingų elementų, o viešujų paslaugų vartotojai skiria prioritetą skirtingoms kokybės dimensijoms. Vartotojų atsakymai i jiems pateiktus klausimynus negali atspindèti realios paslaugų kokybès jau vien dèl to, kad klientų lūkesčiai yra dinamiški, taip pat skirtingas yra piliečių suvokimas, kiek paslaugos galètų ir turètų būti kokybiškesnès lyginant su esamu jų kokybės lygiu. Viešųjų paslaugų tyrimai dažnai yra orientuoti ị paiešką dalykų, kurie gali būti išmatuojami, ignoruojant veiksnius, kurie yra svarbūs iš tikrųjų. Toks informacijos iškreipimas praktikoje dažnai atsiranda dẻl politinio stimulo priimti geras žinias. Nevisapusiški kiekybinès analizės duomenys yra lengvai interpretuojami ir gali būti klaidingai pateikiami siekiant užsitikrinti piliečiu pritarimą esamai viešosios politikos krypčiai. Už klausimo kaip slypi klausimai kiek, kam ir kada viešosios paslaugos turètų būti teikiamos, kurie yra tokie pat svarbūs, o kai kuriais atvejais net svarbesni [1, p. 250]. Analizuojant viešųjų paslaugų kokybę visada svarbu įvertinti ne tik vartotojų požiūrị, bet ir daugybę galutinị paslaugos teikimo rezultatą nulemiančių veiksnių. Dauguma jų, kaip, pavyzdžiui, paslaugas teikiančių darbuotojų motyvacija, yra pavaldūs kokybiniam požiūriui, todèl kokybinių metodų taikymas gali duoti naudingų įžvalgų ir atskleisti iki šiol mažai žinomus viešųjų paslaugų teikimo trukdžius. Iৃvertinus šiuo metu atliekamų viešųjų paslaugų tyrimų orientaciją natūraliai kyla abejonės: ar visada klausiama tinkamų respondentų, ar klausiama reikiamų dalykų, ar rūpimai informacijai gauti naudojamos adekvačios priemonès?

Demokratinio valdymo pletros poreikio suponuoti viešosios politikos ir viešojo administravimo uždaviniai vis labiau reikalauja glaudaus visų sprendimais vieša- 
jame sektoriuje suinteresuotų šalių bendradarbiavimo. Su viešųjų paslaugų teikimu susijusius klausimus analizuojančių tyrẻjų darbai taip pat turètų daryti didesnị poveikị viešajame sektoriuje priimamiems sprendimams ir diegiamoms inovacijoms. Atliekant viešųjų paslaugų tyrimus, kiekybinè metodologija šiuo metu vyrauja ne tik atliekamuose valstybinių institucijų užsakomuosiuose darbuose ir ataskaitose, bet ir mokslinèse publikacijose, kurių skaičius, atsižvelgiant ị viešųjų paslaugų reikšmę gyventojų gerovei bei bendram šalies ekonominiam konkurencingumui, nèra pakankamas. Be abejo, neigti pagrindinius kiekybinių metodų privalumus ir naudą būtų netikslinga. Vis dèlto reikètų atidžiai ịvertinti A. M. Pettigrew [18] išsakomą nuomonę, jog valdymo moksle nusistovejjusi tvarka yra labai patogi, tačiau neskatinanti kurti naujų žinių ir nedrąsinanti judetti link skirtingų piliečių igalinimo formų bei didesnès įtakos priimant sprendimus. Vien tik kurios nors konkrečios metodologijos privalumus pripažįstantis tyrejjas socialinėje realybèje nèra pajëgus ịvertinti visų tiriamos problemos sprendimui aktualių aplinkybių, todèl atliekamų viešųjų paslaugų tyrimų papildymas kokybinio požiūrio elementais šiandien yra itin aktualus.

Šio straipsnio tikslas - išanalizuoti kokybinio požiūrio svarbą viešųjų paslaugų tyrimuose, išryškinant sąveikos tarp suinteresuotųjų reguliavimo bei procesų valdymo reikšmę.

Tikslas ịgyvendinamas teoriniais metodais atskleidžiant esmines kiekybinès metodologijos vyravimo priežastis, aptariant viešųjų paslaugų vertinimo problematiką, identifikuojant ị procesus orientuoto požiūrio elementus bei kokybinių tyrimų metodų privalumus.

\section{Lietuvoje vykdomų viešųjų paslaugų tyrimų kryptys}

Pagal potencialų poveikị viešosios politikos sprendimams Lietuvoje atliekamus viešųų paslaugų tyrimus galima santykinai skirti ị dvi grupes: 1) užsakomuosius tyrimus ir metines ataskaitas; 2) akademiniu lygmeniu publikuojamus darbus.

Vertinant oficialiosios statistikos tyrimus, būtina atkreipti dèmesị ne tik ị perskirstomajji ir institucinị, bet ir ị politinị viešųjų paslaugų kontekstą. Piliečių pasitenkinimas gaunamomis paslaugomis yra viena esminių elektorato palankumo valdžios vykdomai politikai determinančių. Mūsų dienomis kontraktavimo ir privatizavimo sprendimai yra daug mažiau nulemti ideologijos negu pradiniame NVV sklaidos etape. Orientaciją ị konkurecinès viešųjų paslaugų rinkos plètrą ir privataus sektoriaus dalyvavimo skatinimą galima pastebèti apžvelgus daugeli publikuojamų valstybinių ịstaigų užsakomųjų tyrimų bei ataskaitų. Mokslinejje literatūroje visuotinai sutariama, kad privataus sektoriaus įtraukimo ir kontraktavimo sprendimai turètų būti priimami išanalizavus valstybès socioekonomines savybes, egzistuojančias masto ekonomijos galimybes, privačių paslaugų teikejų skaičių ir pajègumą įvertinant atsižvelgiant ị valstybės demografinę struktūrą ir administracinius gebėjimus. Lietuvoje privataus sektoriaus ịtakos didinimo poreikis dažniau 
pagrindžiamas ne visapusiška analize, o skambiais viešųjų paslaugų kokybės ir prieinamumo apibrèžimais. Tokių tyrimų duomenys ir jų pagrindu formuojamos ilgalaikès viešosios politikos kryptys gali suponuoti teigiamus trumpo laikotarpio piliečiu pasitikejjimo vykdomos politikos kursu pokyčius. Kontraktavimas taip pat padeda didinti bendrą visuomenès palankumą rinkai, nes balso teisę turinčių piliečių, dirbančių privačiame sektoriuje, skaičius didejja [26, p. 483].

Būtina pasakyti, kad viešųjų paslaugų teikimas nẻra dažnas Lietuvos mokslininkų diskusijų objektas. Aktualūs viešųjų paslaugų teikimo organizavimo klausimai dažniausiai fragmentiškai analizuojami kitomis temomis parašytų straipsnių ir atliktų tyrimų kontekste. Pažangių valstybių patirtis, skatinanti dalinị grịžimą prie tradicinio viešųjų paslaugų teikimo, parodè, kad orientacija vien tik ị konkurencinès rinkos plètrą dažniausiai nèra veiksmingas pasirinkimas. Bandymai įvardinti viešųjų paslaugų finansavimo ir teikimo prioritetus mūsų šalies mokslininkų tyrimuose didžiąja dalimi vis dar yra paremti viešojo ir privataus sektorių partnerystės bei kontraktavimo teisinès, ekonominès aplinkos ir poveikio viešojo sektoriaus finansams analize. Tuo tarpu darbų, kuriuose būtų orientuojamasi ị naujosios viešosios vadybos evoliucionavimo ị naująji viešąji valdymą nulemtus pokyčius viešųjų paslaugų teikimo srityje ar bandymų ieškoti privatizavimui bei kontraktavimui alternatyvių metodų, nèra daug. Viena iš esminių pasaulines viešųjų paslaugų teikimo organizavimo pokyčių kryptis lemiančių tendencijų - klientų dalyvavimas viešųjų paslaugų teikimo ir organizavimo procesuose - plačiau analizuojama A. Raipos ir E. Petukienès [19] darbuose. Modernių viešųjų paslaugų kokybės vadybos modelių analizès pagrindu parengtą Lietuvos savivaldybėse teikiamų viešųjų paslaugų kokybės gerinimo modeli yra pateikusi G. Kondrotaitė [14].

Vykstančio ribų tarp valstybès, verslo, pilietinès visuomenès, nacionalinių ir tarptautinių valdymo struktūrų nykimo fenomenas yra esminis veiksnys, reikalaujantis visų sprendimais suinteresuotų asmenų įtraukimo ị viešosios politikos formavimo procesus. Valdymo mokslų indèlị ị visuomenès pažangą užtikrina ne valdymo procesų išmanymas, bet abejojimas praktikoje nusistovejusia tvarka ir nuolatiné kritika. Kad tyrimų metu sukauptos žinios atsispindètų viešosios politikos sprendimuose, pirmiausia būtina politinè valia. Mokslininkai turi ịsipareigoti valdžios sistemoms, bet atsispirti patogiam pasirinkimui tapti tų valdžios sistemų sekejjais [18, p. 977]. Mokslo įtaka politikos formavimo procesuose turi pasireikšti naujomis žiniomis grindžiamų požiūrių ịterpimu, o ne esamų politikos krypčių ar kurios nors suinteresuotųjų grupès palaikymu.

Organizuojant viešųjų paslaugų teikimą pasauliniu mastu ryškẻja paslaugų pritaikymo individualiems poreikiams, piliečių dalyvavimo, bendrojo paslaugų kūrimo tendencijos. Tuo pat metu didejja ir poreikis tyrimų, leidžiančių suprasti teikiant paslaugas dalyvaujančių asmenų sąveiką lemiančius veiksnius ir daryti jiems ịtaką. Lietuvos akademiniu lygmeniu toks požiūris sulaukia palaikymo, tačiau realiai viešųjų paslaugų teikimo organizavimui ịtakos turintys tyrimai pagrindinemis paslaugų teikimo inovacijomis vis dar ịvardija elektroninèje terpejje teikiamų pas- 
laugų plètrą, tolesnį vieno langelio principo diegimą, konkurencijos viešųjų paslaugų rinkoje skatinimą.

\section{Viešųjų paslaugų vertinimo rodikliai, trikdžiai ir ribotumai}

Patikima statistika yra demokratiško susitarimo tarp visuomenès ir jos išrinktų valdžios atstovų šerdis [9, p. 327]. Statistinių tyrimų rezultatai yra plačiai naudojami formuojant viešają politiką ir kontroliuojant viešųų paslaugų teikimą. Akivaizdu, kad oficiali statistinè informacija ne tik daro įtaką kasdieniniam piliečių gyvenimui, bet ir prisideda prie jų nuomonès bei nuostatų formavimosi bei valdžios ịstaigų veiklai keliamų reikalavimų. Net paviršutiniška oficialiosios statistikos, pavyzdžiui, savivaldybių metinių ataskaitų, analizè patvirtina teiginį, kad valdžios įstaigos yra linkusios pateikti daugiau teigiamos informacijos apie tas viešujų paslaugų sritis, kuriomis piliečiai labiausiai domisi ir kurios visuomenejje kelia daugiausiai debatų bei neigiamų reakcijų. Nors oficialiosios statistikos rengejjų ir viešosios politikos formuotojų negalima kaltinti duomenų klastojimu, tačiau kyla pagrịstas klausimas, ar priimamus sprendimus pagrindžiantys duomenys visada yra kokybiški, pakankami ir visapusiški. Duomenų gausa nebūtinai reiškia informacijos kokybę. Matavimas yra veiksmingas tiek, kiek ịvertina tai, ką juo numatoma ịvertinti [13, p. 390]. Viešųjų paslaugų pobūdis ir kompleksiškumas daro jų vertinimą žymiai sudètingesnį negu privačiame sektoriuje teikiamų paslaugų, kurių esminiai rodikliai apima tik kainų ir klientų nuomonès aspektus. Pelno siekis nèra ir negali būti svarbiausias viešojo sektoriaus ịstaigų uždavinys, todẻl efektyvumas organizuojant paslaugų teikimą ir gèrybių paskirstymą yra tik vienas iš daugialypių ir neretai sunkiai suderinamų valdžios tikslų. Itin svarbu, kad viešųjų paslaugų vertinimas būtų atliekamas analizuojant įvairius su paslaugomis susijusius procesus ir rodiklius. Tokiai visapusiškai analizei reikalingi ir adekvatūs tyrimų metodai, kur kas ịvairesni už tuos, kurie gali potencialai prisidèti didinant piliečių pritarimą vykdomai politikai ar įvertinti pasirinktų viešųjų paslaugų teikimo metodų reikšmę valstybès finansams.

Viešųjų paslaugų kokybès gerinimo ir prieinamumo didinimo poreikis mažinant viešojo sektoriaus išlaidas nèra vienintelis paslaugų organizavimo ir vertinimo problematiką lemiantis veiksnys. Organizacijų hibridizacijos ir ekonominių sunkumų epochoje mišrios viešųjų paslaugų rinkos kūrimas yra neišvengiamas, tačiau sąlygos viešajame sektoriuje niekada neprilygsta tobulos konkurencijos sąlygoms. Kadangi Adamo Smito „nematoma ranka“ teikiant viešąsias paslaugas paprastai neveikia, laisva suinteresuotų asmenų sąveika užtikrinant veiksmingą viešųjų paslaugų teikimą tiesiog negalima pasikliauti [1, p. 249]. Todèl ne tik viešųjų paslaugų organizavimas, bet atitinkamai ir tyrimai turi apimti viešosios politikos darbotvarkei priskirtinus klausimus, kokias paslaugas, kaip, kam ir kada teikti. Analogiškai išskiriamos ir keturios viešųjų paslaugų efektyvumo dimensijos. Pirmoji, gamybinis efektyvumas, nusako produkcijos maksimizavimo ir sąnaudų santykị; antro- 
ji, išdèstymo efektyvumas, parodo viešųjų paslaugų paklausos ir pasiūlos atitiktị; trečioji, paskirstymo efektyvumas, yra susijusi su apimtimi, kuria vyriausybės gali užtikrinti teisingą paslaugų paskirstymą piliečiams atsižvelgiant ị biudžeto apribojimus; tuo tarpu ketvirtoji, dinaminis efektyvumas, turi įtakos pusiausvyrai tarp esamo ir būsimo vartojimo [1, p. 248].

Viešųjų paslaugų teikimo veiksmingumas apima efektyvumą, tačiau nėra jam tapatus. Veiksmingumas apima ir kokybinius, finansiniais rodikliais neišreiškiamus kriterijus. Tad pirmoji dimensija nėra svarbesnè už kitas. Organizuojant viešųjų paslaugų teikimą tarp šių skirtingų dimensijų būtina ieškoti kompromiso, reiškiančio abipusę orientaciją tiek ị viešųjų paslaugų apimtị, tiek ị turinị ir, savo ruožtu, būtinybę derinti kiekybinius ir kokybinius rodiklius.

Itin problemiški ir daug diskusijų sulaukiantys yra viešųjų paslaugų kokybės tyrimai. Šiuo metu viešojo valdymo teoretikai beveik visuotinai sutaria, jog paslaugų vartotojų vaidmuo yra dvejopas, o kliento nuostatos ir pasirinkimas skiriasi nuo piliečio nuostatų ir valdžios institucijų veiklai keliamų reikalavimų. Oficialiosios statistikos tyrimuose dažniausiai, o ir akademinio lygmens studijose neretai viešųu paslaugų kokybè vertinama atliekant paslaugų vartotojų nuomonès tyrimus. I klientų nuomonę orientuoti viešųjų paslaugų kokybès tyrimai neišvengiamai yra surišti su prieš gaunant paslaugą vartotojų turètais lūkesčiais, todèl parodo ne objektyvią, konkrečiais rodikliais išreiškiamą, o nuo subjektyvaus pasitenkinimo priklausančią kokybę. Kitais žodžiais tariant, suvokiama viešųjų paslaugu kokybė yra vertinimo, kuriuo vartotojas lygina patirtį su lūkesčiais, turètais prieš paslaugos gavimą, rezultatas, lemiamas masto, kuriuo suteikta paslauga atitinka kliento lūkesčius, nustatymo [21, p. 357]. Pasitenkinimo tyrimai sulaukia kritikos dẻl juose dažnai pasitaikančių apklausos rengimo ir atlikimo klaidų bei validumo. Respondentais pasirenkami piliečiai, teikiantys prioritetą skirtingoms paslaugu kokybės dimensijoms ir skirtingai ịsivaizduojantys kiek geresné gautoji paslauga turètų būti. Suinteresuotieji politikos ir procedūrų raida bei ịgyvendinimu iš tokios informacijos negali nieko pasimokyti [22, p. 362]. Paslaugų teikimas visų pirma yra sąveika tarp teikèjo ir gavėjo, todèl bet kokių organizuojamų viešujų paslaugų teikimo pokyčių ịgyvendinimui tarpasmeniniai santykiai yra reikšmingi. Tuo tarpu esminiai piliečių lūkesčius lemiantys veiksniai slypi asmeniniu, nuostatų lygmeniu. Negatyvi su valstybine institucija susijusios patirties įtaka pasireiškia daug stipriau negu teigiamos patirties poveikis [13, p. 399]. Nepasitenkinimo kontroliavimas nebūtinai skatina pasitenkinimą [4, p. 454], o subjektyvus pasitenkinimas neturétų būti pirminiu siekiu užtikrinant realią paslaugų kokybę. Tačiau nepatenkintų klientų skaičiaus mažejimas turès didesnę reikšmę pasitikèjimui viešojo sektoriaus institucijomis ir, galų gale, valdžia, negu jau patenkintų klientų skaičiaus didejimas [13, p. 399-400]. Todèl organizuojant paslaugų teikimą būtina ne tik nustatyti pasitenkinimo paslaugomis lygị, bet ir visapusiškai suprasti nepasitenkinimą lemiančias priežastis. 
Pastebima, jog net skirtingo amžiaus ir išsilavinimo asmenų lūkesčiai dẻl teikiamų viešųjų paslaugų ženkliai skiriasi [11]. Gyventojų atsakymus taip pat veikia ir turima išankstinė nuomonè apie valdžios institucijas bei konkrečias paslaugas teikiančių įstaigų veiklą, naudojimosi paslaugomis dažnis, sąveikos su paslaugų teikẻjais pobūdis. Vertinant iš valstybinès valdžios pozicijų viešujų paslaugų kokybės tyrimų rezultatai turètų būti svarbus piliečių pasitikejjimo rodiklis. Paslaugų teikimo organizavimas visada yra nukreiptas ị piliečių pasitikèjimo valdžia didinimą, nes pasitikejjimas yra būtina demokratinès santvarkos sąlyga, leidžianti veikti nenaudojant tiesioginès prievartos. Nors tokie paslaugų matmenys kaip ịvairiarūšiškumas, tiesioginis pobūdis ir ịstaigos misijos populiarumas veikia nustatomą pasitenkinimo institucija lygi, jie nepasako nieko apie priežastinius pasitenkinimo ir pasitikejjimo ryšius [13, p. 392]. Pavyzdžiui, S. Horsburgh ir kt. atlikto tyrimo rezultatai parodé, kad pasitenkinimas e. valdžios priemonėmis teikiamomis viešosiomis paslaugomis nekoreliuoja su pasitikèjimu valdžia, nors pasitikejjimas yra susijęs su investicijų i e. valdžios plètrą palaikymu [10].

Kartu su naujojo viešojo valdymo idèjų plètra bei bendrojo paslaugų kūrimo skatinimu iš esmès keičiasi požiūris ir ị viešųjų paslaugų teikimo organizavimą. Akcentuojama paslaugų teikimo procesų svarba, pabrèžiama neekonominių viešosios politikos tikslų viršenybė ir teigiama, kad sprendimai neturi būti priimami orientuojantis išimtinai į finansinius rodiklius. Formuojasi naujas požiūris, ịvardijamas kaip viešųų paslaugų savybių dominavimo teorija ar ị procesus orientuota veiklos logika. Šis požiūris priešinamas ị rezultatus orientuotai iš gamybos sektoriaus perimtai teorijai teigiant, kad ị rezultatus orientuota verslo logika reformuojant viešajj sektorių netinka dèl pačių paslaugų kaip proceso, o ne materialaus produkto, savybių.

Procesų svarbą akcentuojančiu požiūriu iš dalies kvestionuojamas požiūris ị viešąją paslaugą kaip ị mainus, kurių šalys gauna vertę lygiai taip pat, kaip ir bet kokiame kitame sandoryje. Ne tik valstybinio sektoriaus parūpinamos nematerialios paslaugos, bet ir apčiuopiamos gerybės priskiriamos viešųjų paslaugų teikimui, kuris vien savo egzistavimu yra vertę kuriantis procesas. Vadinasi, tokie konstruktai kaip „vieša vs. privatu“, „gèrybės vs. paslaugos“ viešosiose paslaugose tiesiog tampa tarpusavy susietais $[29$, p. 435]. I procesus orientuoto požiūrio turinys kelia naujus reikalavimus viešojo valdymo sprendimų prièmimui bei viešojo sektoriaus veiklos vertinimui. Iš privataus sektoriaus perimti ir organizuojant viešujų paslaugų teikimą dirbtinai primesti vertinimo procesai gali sukelti rimtus nesusipratimus jau vien todèl, kad santykiai tarp viešujų paslaugų teikimu suinteresuotų subjektų yra kur kas subtilesni, o įvairių viešojo valdymo aspektų ir procesų priežastingumas daug sudètingesnis negu pardavejo ir kliento santykių organizavimo privačiame sektoriuje sėkmę lemiančių veiksnių. I paslaugas nukreiptų veiklos vertinimo sistemų rezultatai turi būti interpretuojami rūpestingai, atsižvelgiant ị tai, kad jie neturi žymių galimybių valdymo užmojuose bei ignoruoja stiprias ir sudètingas sąveikas tarp ịvairių gyvenimo kokybès dimensijų ir valdymo procesų bei principų 
[14, p. 299]. Viešųjų paslaugų savybių dominavimo požiūris teikia ypatingą svarbą paslaugų teikimo procesų konstravimui. Be viešujų paslaugų savybių dominavimo požiūrio viešųjų paslaugų procesų valdymas ves tik prie efektyvesnių, bet ne veiksmingesnių viešujų paslaugų. Kaip bebūtų, be procesų valdymo toks požiūris tiesiog skatins ,pasižadejjimų paslaugomis“" neįvykdymą [17, p. 149].

Tyrimuose vis dar dažniausiai remiamasi su naujaja viešąja vadyba sietinais viešųjų paslaugų kokybės vertinimo ir valdymo modeliais, tokiais kaip ISO kokybės standartais, subalansuotų rodiklių sistema ir ypač SERVQUAL modeliu. Nors šie iš privataus sektoriaus perimti modeliai vertinant paslaugų kokybę apima ir procesų analizę, tačiau veiksniai, lemiantys viešųjų paslaugų kokybę, yra ịvairesni ir daug sunkiau įvertinami negu privačiame sektoriuje teikiamų paslaugų kokybės atributai. Privačių paslaugų kokybę lemia tik paslaugas teikiančios ịmonės ir kliento ryšiai, o teikiant viešąsias paslaugas svarbūs ne tik galutiniai paslaugos gavejjai, bet ir mokesčių mokètojai, bendruomenès, suinteresuotos verslo įmonės, nevyriausybinès organizacijos, politikai, paslaugas teikiantys darbuotojai ir kiti subjektai, turintys skirtingus viešosios politikos formavimo ir viešujų gèrybių paskirstymo organizavimo interesus. Interesų konfliktai tarp šių dalyvių yra neišvengiami. Kaip rezultatas keičiasi santykių tarp valdžios ir pilietinių institucijų struktūra, o valdžios gebejjimas valdyti tuos santykius yra lemiamas gerinant kokybę ir piliečių pasitenkinimą viešajame sektoriuje. Todèl kokybès priežastys negali būti apribojamos paslaugų teikimu, o turi būti praplèstos tiek ị viešujų paslaugų konstravimo stadiją, tiek ị santykius su organizacijomis, kurios padeda teikti viešąsias paslaugas [20, p. 1492]. Sutariant, kad viešųjų paslaugų kokybės šaltiniai yra daug kompleksiškesni negu privačių paslaugų, būtina pripažinti, jog net atsižvelgiant ị viešųjų paslaugų specifiškumą modifikuotų iš privataus sektoriaus perimtų vertinimo modelių galimybės tiriant viešųjų paslaugų kokybę lemiančius veiksnius ir pagrindžiant viešųjų paslaugų organizavimo sprendimus yra ribotos. Vis dẻlto bandymų sukurti alternatyvius, viešujjų paslaugų teikimo procesus visapusiškai ịvertinančius modelius yra vos keletas.

Pavyzdžiui, S. K. Rhee ir J. Y. Rha kritikuodami SERVQUAL ir konstruodami alternatyvų viešujų paslaugų kokybės modelị identifikuoja keturis pagrindinius viešųjų paslaugų kokybės elementus - proceso kokybę, rezultatu kokybę, konstrukcijos kokybę, santykiu kokybę. Šių tyrèjų požiūris unikalus tuo, kad viešąsias paslaugas teikiančius asmenis jie laiko tarpiniais klientais ir teigia, jog galutiniai klientai (asmenys, kuriems paslaugos teikiamos) teikia prioritetą proceso ir rezultatų kokybei, tuo tarpu tarpiniai klientai labiau rūpinasi paslaugų dizaino ir santykių kokybe [20]. Modelị autoriai išbandè tirdami socialines paslaugas, kadangi būtent šios viešujų paslaugų grupès kokybės vertinimas labiausiai reikalauja orientacijos ị lygybę ir grịžtamąjį ryšs̆i, ką vartotoją kaip klientą traktuojantys modeliai ignoruoja.

Kuriami teorinius šiuolaikinio viešojo valdymo turinio elementus iš dalies aprẻpiantys modeliai papildo viešųjų paslaugų tyrimų metodologiją, tačiau neužsitikrina tvirtų pozicijų praktiniuose tyrimuose. 


\section{Orientacija ị procesus: veiksniai, kurie turètụ būti analizuojami}

\section{Dabartinị laikmetị tikslinga apibūdinti kaip mišrių, hibridinių organi-} zacijų erą. Ikivadybinėmis koncepcijomis paremtų viešojo sektoriaus reformų igyvendinimo ir vèlesnių bandymų skatinti demokratinius viešojo valdymo procesus valstybės institucijų, pelno siekiančių firmų bei nevyriausybinių organizacijų savybės ir tikslai buvo laikomi unikaliais konkretaus sektoriaus atributais, leidžiančiais lengvai atskirti viešojo, privataus ir visuomeninio sektorių veiklos sritis. Šiuolaikinès, nuo tinklaveikos idejų neatsiejamos viešojo valdymo koncepcijos remiasi skirtingų sektorių organizacijų sąveika, todèl ir viešųjų paslaugų teikimas neišvengiamai turi būti analizuojamas ịvairialypejje institucinèje aplinkoje.

Organizacijų hibridizacijos fone kertiniai klausimai organizuojant viešųjų paslaugų teikimą apima paslaugas teiksiančios organizacijos pasirinkimą ir efektyvių šių organizacijų veiklos kontrolès mechanizmų formavimą. Procesų svarbą akcentuojančio požiūrio šalininkams susirūpinimą kelia ne pats efektyvumo siekis, bet ị rezultatus orientuoto požiūrio įtaka viešųjų paslaugų teikime dalyvaujančiu asmenų santykiams. Praktikoje reformos dažnai remiasi kontrolę, biurokratizaciją ir standartizaciją skatinančiomis priemonėmis. Teikiant viešąsias paslaugas dalyvaujančių subjektų veiklos vertinimas pagal iš anksto nubrèžiamus tikslus ir nustatomus atlikimo rodiklius viešajame sektoriuje skatina konkurenciją. Konkurencinè sąveika yra tinkama, jeigu yra vaikomasi tik efektyvumo didejjimo, tačiau kai siekiama, kad mišri aplinka būtų naudinga taip pat ir perskirstymo funkcijai, bendradarbiavimo santykiai yra tinkamesni [28, p. 18].

Bet koks viešujų paslaugų teikimo modelis turi prielaidas, susijusias su paslaugų teikimo srityje dirbančių asmenų motyvacija. Orientaciją ị rezultatus akcentuojančios reformos neskyrė daug dėmesio tarnautojų ir paslaugų gavėjų sąveikos aspektams. Savanaudiškos valstybès tarnautojų prigimties akcentavimas ir etinių savybių svarbos sumenkinimas lèmé finansinès naudos, kaip pagrindinio veiksnio pasirenkant viešųjų paslaugų teikẻją, įsigalèjimą. Sprendimų pagrindimas buvo nukreiptas ne ị fizinių asmenų, o ị organizacijų kaip subjektų sąveiką. Vis dèlto valstybės siekis į viešųjų paslaugų teikimo procesus įtraukti ne viešojo sektoriaus organizacijas buvo analizuojamas ir pagrindžiamas remiantis tarp pavienių individų sudaromų susitarimų turiniu. Organizacijų sąveikos analizavimas per savanaudiškos prigimties individų racionalaus elgesio prizmę yra netikslingas jau vien dèl to, kad valstybinių organų sprendimai turi būti nukreipti ị gerovès visuomenei, o ne viešojo sektoriaus darbuotojams kūrimą. Kontraktai, kuriuose tiesiogiai ar kaip kontroliuojantis organas dalyvauja valstybinè institucija, iš esmès skiriasi nuo asmeniniu ar tarporganizacinių susitarimų, kuriais siekiama naudos tik sutarties šalims. Todèl viešųjų paslaugų teikimas turi būti organizuojamas ịvertinant ne vien finansinius ir institucinius, bet ir socialinius bei vertybinius veiksnius.

I procesus orientuotos veiklos logikos asmeninėms žmonių savybėms teikiama reikšmé visapusiškai prieštarauja teorinių NVV ramsčių, viešojo pasirinkimo bei 
sandorio kaštų teorijų požiūriui. Akcentuojama, kad viešųjų paslaugų teikimo nesėkmès dažnai slypi piliečių ir paslaugas teikiančių asmenų santykių mikrolygmeniu. Pastebima, kad teigiamas piliečių požiūris ị tam tikras viešąsias paslaugas ir neigiamas požiūris ị viešojo sektoriaus institucijų veiklą gali koegzistuoti, o pats paslaugos turinys nèra esminis pasitikejjimą skatinantis veiksnys. Piliečiams dažnai daug svarbiau tai, kaip įstaigos prisideda prie gyvenimo kokybès ir kaip jų veikla atitinka gerojo valdymo principus, tokius kaip skaidrumas, konsultavimasis su paslaugų gavèjais ir sąžiningumas [2, p. 299]. Jei piliečių pasikliovimas ir pasitikèjimas valstybinèmis institucijomis yra aukštas arba didèja, tai galima pagrịstai manyti, kad valstybinès institucijos vykdo savo demokratinę misiją net esant nesėkmėms ir nusivylimui specifinėse srityse. Jei piliečių pasitikejjimas yra mažas arba smunka, tai net pabréžiant tam tikrų viešosios politikos sričių ar programų pasiekimus valdymą vertinti kaip sèkmingą yra daug sunkiau $[8$, p. 553]. Bet kokios viešojo sektoriaus organizacinès reformos yra nukreiptos ị visuomenès pasitikejjimo didinimą, todèl ir reformų rezultatų vertinimas turi apimti pasitikèjimo pokyčių analizę bei nepasitikèjimą lemiančių veiksnių paieškas. R. C. Nyhan teigimu, pasitikejjimas viešajame sektoriuje gali būti vertinamas iš vidinès (organizacinès) ir išorinės (aplinkos) perspektyvų, kurios abi yra vienodai svarbios, o pats pasitikèjimas yra sudarytas iš trijų pagrindinių iš dalies sutampančių konstruktų: sąžiningumo, pasikliovimo, rizikos prisièmimo [16, p. 89]. Todèl visuomenès pasitikejjimo problema negali būti išspręsta vien kontroliuojant tarporganizacinius susitarimus. Būtinas paslaugų teikimo procese dalyvaujančių asmenų santykių reguliavimas asmeniniu lygmeniu. Svarbi ne tik galutinių paslaugų gavejų suvokiama paslaugos kokybė, bet ir pasitikejjimas tarp politikų ir tarnautojų, aukštesniųjų tarnautojų pasitikejimas tiesiogiai paslaugas teikiančiais darbuotojais, viešąsias paslaugas teikiančių nevalstybinių subjektų ir viešojo sektoriaus ịstaigų abipusis pasitikejjimas.

Procesų svarbą pabrèžiančio požiūrio šalininkai ị rezultatų siekị mažinant kaštus nukreiptose reformose pasigenda paslaugų vadybos teorijos principų paisymo ir filosofijos perèmimo. Abejojama šūkiu „padaryti daugiau išleidžiant mažiau“ apibendrinamų viešųjų paslaugų teikimo organizacinių formų tinkamumu siekiant visuomenės interesų patenkinimo ir pasitikẻjimo tarp suinteresuotųjų paslaugų teikimu skatinimo. Keliamos idèjos apibūdinamos kaip ,padaryti daugiau pasitelkiant daugiau“, kurios nebūtinai reiškia viešojo sektoriaus tiesiogiai teikiamų paslaugų skaičiaus didinimą, bet pabrèžia sąlygų, leidžiančių teikiant paslaugas išnaudoti potencialius visuomenès ir verslo pajëgumus, užtikrinimo svarbą [7]. Kuriant mišrias viešųjų paslaugų rinkas orientacija ị procesus yra būtina jau vien dèl to, kad pagrindinès žinių taikymo ir inovacijų igyvendinimo kliūtys yra susijusios su žmonėmis, jų motyvacija, nuostatomis, požiūriais, atvirumu naujovėms. Todèl, kad ir kokią didelę naudą organizuojant viešujjų paslaugų teikimą duoda ekonominių veiksnių analizè, ne mažiau svarbu tirti teikiant paslaugas dalyvaujančių asmenų elgesị lemiančius motyvus bei vertybes ir igyvendinti strategijas, nukreiptas ị tinkamą suinteresuotųjų sąveiką, be kurios taupymo reformos yra pasmerktos žlugti. 
Mišriose viešųjų paslaugų rinkose pagrindiniu ekonominị efektyvumą lemiančiu veiksniu tampa konkurencija. Valstybės tarnautojų reikšmė tiesiogiai teikiant paslaugas mažeja, tačiau jiems paliekamas ne mažiau svarbus vaidmuo valdyti viešųjų paslaugų rinką. Konkurencinių sąlygų užtikrinimas yra sudètingas uždavinys ne tik dèl teisinių ir politinių suvaržymų bei dažnai nepakankamo egzistuojančių potencialių viešųjų paslaugų teikèjų skaičiaus, bet dar ir dèl to, jog daugumai valstybės tarnautojų konkurencija yra sunkiai suvokiamas tikslas [12, p. 21]. Reformų rezultatus lemia ne tiek ideologiné polemika apie tinkamą valstybès vaidmenị ir veiklos viešųjų paslaugų rinkoje apimtis, kiek viešosios politikos programas ịgyvendinančių asmenų motyvacijos klausimai, kurių sprendimas reikalauja intervencijos ir negali būti paliktas savireguliacijai. Nagrinejjant tarnautojų motyvaciją pradiniu atspirties tašku gali būti J. Le Grand naudojamas teorinis valstybès tarnautojų skirstymas ị dvi grupes, priskiriant jiems savanaudiškus arba altruistinius veiklos motyvus ir atitinkamai šias grupes įvardijant „niekšais“ (knaves) ir „riteriais“ (knights) [15]. Vis dèlto tiek išimtinai asmeniniais interesais besivadovaujantys, tiek bendrojo gèrio siekiantys ir troškimo gerai teikti viešąsias paslaugas vedini tarnautojai dažnai priešinasi ekonominèmis vertybėmis grindžiamų reformų ịgyvendinimui. Tarnautojų nepritarimą į mišrios viešųjų paslaugų rinkos plètrą nukreiptoms programoms stiprina ne tik kartu igyvendinamos viešojo sektoriaus ìstaigu personalo mažinimo reformos, bet ir netikejimas pokyčių nauda visuomenès gerovei. Vykdant viešojo sektoriaus išlaidų mažinimu grindžiamas reformas sukuriama tokia situacija, kad daugelis valstybės tarnautojų jaučiasi prarandantys savo igaliojimus ir turi igyvendinti sprendimus, priešingus jų asmeninėms ir profesinèms vertybėms [3, p. 20]. Net jei karjeros pradžioje vedami viešajam sektoriui palankių stimulų tarnautojai elgiasi kaip riteriai, išimtinai išorinio pobūdžio paskatų struktūra gali privesti prie jai būdingos motyvacijos ir tokiu būdu riterius paversti niekšais. Reikalinga stipri motyvavimo sistema, kuri būtų patraukli riteriams ir niekšams, skatintų vienodą abiejų grupių elgesị [15, p. 68]. Todèl ekonominių sunkumų laikmečiu ịgyvendinti išimtinai valstybinių institucijų personalo mažinimu ir konkurencinių sąlygų sudarymu pagrịstas viešųjų paslaugų teikimo strategijas nèra tikslinga. Siekiant efektyvumo kartu būtina skirti dèmesị valstybės tarnautojų lavinimui, žinių valdymo procesų tobulinimui ir ne konkurencine sąveika, o bendradarbiavimu grindžiamų inovacijų diegimui.

Bendradarbiavimo procesų tobulinimo poreikị skatina pats viešojo valdymo tinklų ir mišrios viešųjų paslaugų rinkos egzistavimas. Nors dažniausiai pabrèžiama bendradarbiavimo svarba bendrai demokratijos raidai, šie procesai taip pat yra svarbūs ir finansinių viešojo sektoriaus veiklos rodikliu gerinimui. Tinklinio valdymo modelyje ne konkurencijos ir varžymosi skatinimas, o partnerystė tampa svarbiausiu viešojo sektoriaus konkurencingumą lemiančiu veiksniu, nes leidžia vystyti veiklą pasinaudojant žiniomis, kurių ekonominių, teisinių ir politinių apribojimų varžomos valstybinės institucijos pačios neturi ar negali taikyti. Bendradarbiavimas igalina viešojo sektoriaus ịstaigas kurti vertę valstybei, verslui ir visuomenei pasi- 
naudojant pačių pelno sektoriaus organizacijų ir bendruomenès narių patirtimi bei įsipareigojimais. Būdamas neatsiejamas nuo konsultavimosi su visuomene procesų, bendradarbiavimas tampa ir viena iš pagrindinių viešojo sektoriaus veiklos kontrolès formų. Piliečių reikalavimai prisideda gerinant viešųjų paslaugų kokybę ne tik srityse, kuriose bendrojo paslaugų kūrimo koncepcijos idẻjos yra lengvai igyvendinamos, bet ir nustatant veiklos standartus ir įvykdymo terminus sektoriuose, kuriuose viešosios paslaugos negali būti individualizuojamos. Potenciali bendradarbiavimo nauda yra neginčijama, tačiau tinkamas bendradarbiavimo ir konsultavimosi procesų organizavimas yra itin sudètingas, ̨̇vairialypių tyrimų ir metaanalizès reikalaujantis uždavinys.

I procesus orientuotų reformų pranašumas lyginant su ị rezultatus orientuota viešojo sektoriaus veiklos organizavimo logika pagrindžiamas poreikiu daryti įtaką teikiant viešąsias paslaugas dalyvaujančių asmenų sąveikai. Sąveikos plotmejje kiekybiniu požiūriu paremti tyrimai gali suteikti naudingų įžvalgų, paremtu jau egzistuojančių santykių analize. Kiekybiniai tyrimai gali padèti hipotezès testavimui ir statistiniam apibendrinimui [27, p. 557]. Tačiau pati sąveika yra nuolat kintantis procesas. Kokybinis požiūris yra grindžiamas lankstesniais metodais ir sudaro geresnes galimybes numatyti ịvairių procesų priežastinius ryšius bei asmenų elgesio perspektyvas.

\section{Kokybinių tyrimų metodų reikšmė}

Kokybinio požiūrio plètros poreikị viešųjų paslaugų tyrimuose skatina ne klausimas dẻl kiekybinių metodų tinkamumo, bet veikiau diskusija dẻl jų nepakankamumo sprendimų prièmimui reikalingų visapusiškų žinių kaupimui, tinkamai duomenų interpretacijai ir galimybėms mokytis iš analizės rezultatų. Kokybinio požiūrio šalininkai pasisako ne už kiekybinių metodų atsisakymą ar radikalius viešųjų paslaugų tyrimų metodologijos pakeitimus, o už platesnị kokybinių metodų taikymą tiriant kiekybiškai sunkiai ịvertinamus, tačiau valdžios įstaigų tikslų ịgyvendinimą lemiančius veiksnius ir procesus.

Kiekybinès metodologijos pagrindu vykdomų tyrimų papildymo kokybiniais metodais poreikis nèra vienodas visose viešųjų paslaugų srityse. Bendru požiūriu kokybinių metodų privalumai gali būti sẻkmingai išnaudojami tiriant paslaugas, pasižyminčias intensyvia paslauga besinaudojančių ir ją teikiančių asmenų sąveika. Kiekybiniai metodai laikomi tinkamais palyginti paprastoms paslaugoms, kuriu kokybę klientai suvokia vertindami paslaugos turini, o ne patyrimą paslaugos teikimo proceso metu. Vis dèlto, net vertinant tokias viešąsias paslaugas kaip vandens tiekimas ar komunalinių atliekų tvarkymas, piliečių suvokiama paslaugos kokybẻ negali būti pakankamu objektyvaus viešųjų paslaugų organizavimo įvertinimo matu. Kokybinių metodų potencialas pirmiausia galètų būti išnaudojamas organizuojant bet kurios srities viešujų paslaugų teikimą. Paslaugų teikimo organizacinių modelių formavimas iš esmès apima pasirinkimą veiklos krypčių, kai organizacija 
paslaugų teikimui reikalingas sąnaudas transformuoja į norimą išeigą. Šis pasirinkimas turi techninę ir politinę dimensijas [24]. Jeigu priimant sprendimus orientuojamasi daugiau i techninę pusę ir remiamasi vien efektyvumo bei finansinių rodiklių matavimu, tai galima teigti, jog viešųjų paslaugų teikimo organizavimas neturi aiškios ilgalaikès krypties, o yra orientuotas tik ị paviršutinišką finansinių viešojo sektoriaus problemų sprendimą. Politinis pasirinkimas turètų apimti dinaminị sąnaudų ir laukiamos išeigos ịvertinimą, nes viešosios paslaugos turi ịtaką visuomenès ir valstybės raidai ilgalaikèje perspektyvoje. Visuomenès transformacijos procesas negali būti paaiškinamas vien tik vadybine veikla ir su ja susijusiomis efektyvumo ir veiksmingumo kampanijomis [18, p. 975]. Efektyvumo matavimai gali duoti naudingų įžvalgų visuminiam viešųjų paslaugų teikimo organizavimo procesui, tačiau efektyvumo rodikliai negali būti universaliu siekiniu organizuojant viešąsias paslaugas teikiančių ịstaigų veiklą. Svarbu, kad techniniai ir politiniai pasirinkimai būtų aiškiai atskirti ir kad analitikai siektų konsultavimosi su politikos formuotojais priimant sprendimus - tokius kaip išeigos pasirinkimas - kurie iš tikrųjų yra politinio pobūdžio [24, p. 415]. Strateginiu politiniu tikslu organizuojant viešųjų paslaugų teikimą turètų būti demokratinių valdymo procesų integravimas ir, be abejo, visuomenès pasitikejjimo, kaip tinkamo gerojo valdymo standartų užtikrinimo indikatoriaus, skatinimas. Jeigu tikslas yra visuomenės pasitikèjimas ir pasitenkinimas viešosiomis paslaugomis, tai kiekybinių metodų nauda yra ribota [22, p. 363], o pasitenkinimo apklausos negali suteikti visapusiškos informacijos apie esminius piliečių nepasitikèjimą lemiančius veiksnius.

A. Soteri-Proctor [25] skiria tris pagrindinius kokybinių metodų privalumus: lankstumą, tinkamumą procesų suvokimui, galimybę vertinti paslaugų teikimo procesą iš personalo perspektyvos. Šias kokybinių metodų savybes autore analizuoja vertindama trečiojo sektoriaus ịgalinimą teikiant viešąsias paslaugas. Vis dèlto piliečiu pasitikẻjimo neužtikrinimas dažniausiai atspindi arba nesėkmes viešosios politikos programose ir vadovų konstruojamose procedūrose, arba tarnautojų nesugebejjimą dirbti pagal keliamus reikalavimus, arba abi problemas [22, p. 363]. Todèl ịvardinti kokybinių metodų privalumai yra reikšmingi visiems su viešųjų paslaugų teikimu susijusiems pasirinkimams. İvairių viešųjų paslaugų teikimo procesų priežastinių ryšių nustatymas yra itin svarbus, nes leidžia suprasti, kodèl problemos atsiranda, kaip jos vystosi ir kokią įtaką daro laukiamiems paslaugų teikimo rezultatams. Procesų ịvertinimas iš personalo pozicijų leidžia ịvertinti paslaugas teikiančių asmenų netinkamą elgesį sąlygojančias priežastis ir motyvuoti personalą veikti taip, kad būtų pasiekti numatyti tikslai. Taigi išryškejja dar vienas itin svarbi kokybinių priemonių savybė - galimybé formuoti tyrimuose dalyvaujančių asmenų požiūrị ir keisti jų elgseną. Paslaugas teikiantys asmenys nèra tik neutralūs funkcionieriai, kaip ir paslaugomis besinaudojantys piliečiai nèra vien asmenine nauda suinteresuoti klientai. Visiems jiems būdingos išankstinès nuostatos ir gebejjimas kritiškai mąstyti. 
Mažindama viešojo sektoriaus išlaidas valstybė gali pasiekti savo viešųjų paslaugų teikimo tikslus tik remdamasi nevalstybinių subjektų veikla. Konstruktyviam šios sąveikos organizavimui neužtenka formalių kontrolès mechanizmų ir reikia kur kas daugiau negu rezultatų generavimo. Net privataus sektoriaus dalyvavimas teikiant viešąsias paslaugas turi būti suprantamas atsižvelgiant ị nekontraktinius socialinius, politinius ir institucinius veiksnius, tarp kurių yra realizuojamas [5, p. 1073]. Konkurencijos viešųjų paslaugų rinkoje skatinimas yra priemoné piliečių atžvilgiu valstybės prisiimamų ịsipareigojimų vykdymui, o ne savaiminis valstybinio valdymo tikslas. Mišrios viešųjų paslaugų rinkos yra kuriamos siekiant pasinaudoti sąveikos tarp skirtingų sektorių organizacijų, taip pat ir pavienių paslaugu gavejjų teikiama nauda. Todèl konkurencija teikiant viešąsias paslaugas negali egzistuoti be bendradarbiavimo. Nors bendradarbiavimas dažnai gali būti inicijuojamas kaip strateginis atsakas aplinkos ir finansiniam neapibrèžtumui [6, p. 654], tačiau šiuolaikiniame viešajame valdyme bendradarbiavimas teikiant viešąsias paslaugas turi būti skatinamas esant bet kokioms sąlygoms. Mišrių savybių organizacijų ir tinklinės biurokratijos eroje bendradarbiavimas tampa sékmingo viešųjų paslaugų teikimo organizavimo garantu, o konkurencinẻ sąveika gali tik papildyti, bet ne pakeisti partnerystės ryšius. Nauja sẻkmės definicija reikalauja naujo praktinio požiūrio, pagrịsto geru suvokimu, kaip sąveika teikiant paslaugas vyksta [23, p. 130]. Suinteresuotieji viešųjų paslaugų teikimu ir paslaugų teikimo procesuose dalyvaujantys asmenys turi suvokti savo elgesio reikšmę ir galimybes daryti įtaką tiems procesams. Būtina skatinti pagarbą viešojo intereso vertybèms ir etiniams veiklos standartams. Siekiant šių tikslų mokymasis iš kokybinès analizės rezultatu gali pasitarnauti kur kas labiau negu vien statistiniais metodais sukauptu žinių interpretavimas.

\section{Išvados}

1. Polinkis priimant sprendimus remtis tradiciškai nusistovejjusiomis tyrimų kryptimis gali būti suponuotas politinio ir ideologinio konteksto. Siekiant teigiamu visuomenès ir valstybės raidos pokyčiu ilgalaikèje perspektyvoje, būtinas abipusis politikų ir tyrejų supratimas, jog mokslo įtaka politikos formavimo procesuose turi pasireikšti nuolatine valdymo procesų kritika ir naujų, tyrimų rezultatais grindžiamų požiūrių ịterpimu.

2. Subjektyviai suvokiama paslaugų kokybė negali atspindèti realios viešujų paslaugų sistemos būklès, o visuomenès nepasitenkinimą ir pasitikèjimo valdžios įstaigomis pokyčius skatina ne tik paslaugų turinys, bet ir paslaugų gavejjų kaip piliečių nuostatos bei patyrimas paslaugos teikimo proceso metu.

3. Vertinant iš ị procesus orientuotos veiklos logikos teorinių pozicijų, esminè metodologinė ir praktinè klaida siekiant suderinti daugialypius politinius viešųų paslaugų teikimo tikslus yra sprendimų pagrindimas vien techniniais efektyvumo ir produktyvumo matavimais. 
4. Laikmečio pokyčiai viešajame valdyme reikalauja viešųjų gėrybių teikimo procesuose išnaudoti verslo ir visuomenès pajègumus, o priimant sprendimus remtis visų suinteresuotųjų pusių sąveika. Konkurencijos skatinimas teikiant viešąsias paslaugas turètų tik papildyti bendradarbiavimo ir konsultavimosi procesus, bet netapti terpe, kurioje šie procesai yra organizuojami.

5. Esminiu viešojo sektoriaus konkurencingumą ir viešųjų paslaugų teikimo sėkmę lemiančiu veiksniu neabejotinai tampa santykių tarp suinteresuotųjų viešųjų paslaugų teikimu kontroliavimas ne tik organizaciniu, bet ir asmeniniu lygmeniu. Kartu didejja reikšmè tyrimų, leidžiančių suprasti teikiant viešąsias paslaugas dalyvaujančių asmenų elgesio motyvus ir daryti įtaką jų sąveikai.

6. İvairių teikiant viešąsias paslaugas dalyvaujančių subjektų sąveiką lemiančių procesų bei veiksnių priežastinių ryšių, kaip žingsnių, vedančių prie norimos išeigos, nustatymas ir ne vien formalus reguliavimas organizuojant viešųjų paslaugų teikimą turètų būti strateginis uždavinys.

7. Šiuolaikinio viešojo valdymo turinys ir viešųjų paslaugų rodiklius lemiančių procesų kompleksiškumas suponuoja skirtingom teorinèm ir metodologinėm prieigom besiremiančių, ne vien finansinius, bet ir vertybinius veiksnius ịvertinančių tyrimų poreikị.

8. Kiekybinių tyrimų rezultatai dažniausiai tik parodo problemų egzistavimą, tuo tarpu kokybinè analizè leidžia visapusiškai suvokti tas problemas. Siekiant, kad tyrimai netaptų tik duomenų kaupimo priemone, o realiai padètų gerinti viešujų paslaugų teikimą, tikslinga derinti kiekybinès metodologijos ir kokybinio požiūrio elementus.

\section{Literatūra}

1. Andrews, R.; Entwistle, T. Four Faces of Public Service Efficiency: What, How, When and for Whom to Produce. Public Management Review, 2013, 15(2), 246-264.

2. Bovaird, T.; Loeffler, E. Assessing the Quality of Local Governance: A Case Study of Public Services. Public Money \& Management, 2007, 27(4), 293-300.

3. Broussine, M.; Ahmad, Y. Development of Public Managers Reflexive Capacities. Teaching Public Administration, 2012, 31(1), 18-28.

4. Carvalho, C.; Brito, C. Assessing Users Perceptions on How to Improve Public Services Quality. Public Management Review, 2012, Vol. 14, Issue 4, 451-472.

5. Dagdeviren, H.; Robertson S. A. A Critical Assessment of the Incomplete Contracts Theory for Private Participation in Public Services: The Case of the Water Sector Ghana. Cambridge Journal of Economics, 2013, 37(5), 1057-1075.

6. Gazley, B. Linking Collaborative Capacity to Performance Measurement in Government-Nonprofit Partnerships. Nonprofit and Voluntary Sector Quarterly, 2010, 39(4), 653-673.

7. Hambleton, R.; Howard, J. Public-Based Leadership and Public Service Innovation. Local Government Studies, 2013, Vol. 39, No. 1, 47-70. 
8. Heintzman, R.; Brian M. People, Service and Trust: Is There a Public Sector Service Value Chain? International Review of Administrative Sciences, 2005, Vol. 71(4), 549-575.

9. Holt, D. T. Official Statistics, Public Policy and Public Trust. Journal of the Royal Statistical Society, 2008, Vol. 171, No. 2, 322-346.

10. Horsburgh, S., Goldfinch, S.; Gauld, R. Is Public Trust in Government Associated With Trust in E-Government? Social Science Computer Review, 2011, 29(2), 232-241.

11. Jilke, S.; Walle, S. V. Two Track Public Servises? Citizens' voice behaviour towards liberalized services in the EU15. Public Management Review, 2012, iFirst article, $1-12$.

12. Johnston, J. M.; Girth, A. M. Government Contracts and "Managing the Market": Exploring the Costs of Strategic Management Responses to Weak Vendor Competition. Administration and Society, 2012, 44(1), 3-29.

13. Kampen, J. K.; Van de Walle, S.; Bouckaert, G. Assessing the Relation Between Satisfaction With Public Service Delivery and Trust in Government. Public Performance \& Management Review, 2006, Vol. 29, No. 4, 387-404.

14. Kondrotaite, G. Evaluation of the Quality of Public Services in Lithuanian Municipalities. Intellectual Economics, 2012, Vol. 6, No. 3(15), 393-411.

15. Le Grand, J. Knights and Knaves Return: Public service Motivation and The Delivery of Public Services. International Public Management Journal, 2010, 13(1), 56-71.

16. Nyhan, R. C. Changing the Paradigm: Trust and its Role in Public Sector Organizations. The American Review of Public Administration, 2000, 30, 87-109.

17. Osborne, S. P.; Radnor, Z.; Nasi, G. A New Theory for Public Service Management? Toward (Public) Service-Dominant Approach. American Review of Public Administration, 2012, 43(2), 135-158.

18. Pettigrew, A. M. The Character and Significance of Management Research on the Public Services. Academy of Management Journal, 2005, Vol. 48, No. 6, 973-977.

19. Raipa, A.; Petukienė E. Klientų dalyvavimas viešosiose paslaugose: bendrasis paslaugų kūrimas.Viešoji politika ir administravimas, 2009, Nr. 27, 54-61.

20. Rhee, S. K.; Rha, J. Y. Public Service Quality and Customer Satisfaction: Exploring the Attributes of Service Quality in the Public Sector. The Service Industries Journal, 2009, Vol. 29, No. 11, 1491-1512.

21. Sanchez-Perez, M. et al. Service Quality in Public Services as a Segmentation Variable. The Service Industries Journal, 2007, Vol. 27, No. 4, 355-369.

22. Shilston, T. G. One, Two, Three, What Are We Still Counting for? Police Performance Regimes, Public Perceptions of Service Delivery and the Failure of Quantitative Measurement. Policing, 2008, Vol. 2, No. 3, 359-366.

23. Shilston, T. G. Black Box: A Qualitative Method for Improving Public Confidence in Policing Through Micro-Analyzing Service Delivery. Policing, 2011, Vol. 5, No. 2, 125-131.

24. Smith, P. C.; Street, A. Measuring the Efficiency of Public Services: The Limits of Analysis. Journal of the Royal Statistical Society, 2005, Vol. 168, No. 2, 401-417.

25. Soteri-Proctor, A. Making Use of Qualitative Tools: Towards a Fuller Understanding of The Voluntary sector's Engagement With Public Service Delivery. International Journal of Social Research Methodology, 2010, Vol. 13, No. 5, 411-424. 
26. Sundell, A.; Lapuente, V. Adam Smith or Machiavelli? Political Incentives for Contracting out Local Public Services. Public Choice, 2012, 153, 469-485.

27. Tummers, L. Explaining the Willingness of Public Professionals to Implement New Policies: a Policy Alienation Framework. International Review of Administrative Sciences, 2011, Vol. 77(3), 555-581.

28. Van der Heijden, J. Interacting State and Non-State Actors in Hybrid Settings of Public Service Delivery. Administration \& Society, 2013, March 19, 1-23.

29. Wright, G. H.; Chew, C.; Hines, A. The Relevance and Efficacy of Marketing in Public and Non-profit Service Management. Public Management Review, 2012, Vol. 14, Issue 4, 433-450.

\title{
Marius Urvikis \\ Trends of Public Services Research: Reasoning the Need for the Development of Qualitative Approach
}

\begin{abstract}
The objective of this article is to dispute the importance of qualitative approach in the research of public services. The paper analyzes theoretical and methodological fundamentals of public services research. The need for the development of qualitative tools is substantiated by revealing the core problems of organizing and evaluating public service delivery as well as theoretical dimensions of service-dominant logic. The first part of the paper examines public services research in Lithuania. The second part deals with indicators, disturbances and limitations of the evaluation of public services. Factors that should be analyzed toward service-dominant approach are discussed in the third chapter, and the importance of qualitative tools is motivated in the last one. This article is not intended to be anti-quantitative, but it draws inference that it is advisable to combine the elements of quantitative methodology and qualitative approach. It is stated that qualitative analysis allows a comprehensive understanding on links of the processes and factors that determine the problems of public service delivery, while quantitative tools usually show the existence of such problems. The paper also stresses potentialities of qualitative approach on tempering interactions among all the parties concerned with public service delivery, as such interactions tend to be the main contributors of public sector's competitiveness in a contemporary era of hybrid settings.
\end{abstract}

Marius Urvikis - Mykolo Romerio universiteto Politikos ir vadybos fakulteto Viešojo administravimo instituto doktorantas.

E. paštas: mariusurvikis@gmail.com

Marius Urvikis, Mykolas Romeris University, Faculty of Politics and Management, Department of Public Administration, Doctoral student.

E-mail: mariusurvikis@gmail.com

Straipsnis įteiktas redakcijai 2014 m. kovo 21 d.; recenzuotas; parengtas spaudai $2014 \mathrm{~m}$. gegužès $25 \mathrm{~d}$. 